\title{
遺尿症での等容性排尿筋収縮圧の測定
}

\begin{tabular}{|c|c|c|c|c|}
\hline \multirow{5}{*}{$\begin{array}{l}\text { 愛媛大学医学部泌尿器科学教室 } \\
\text { (主任: 竹内文教授) }\end{array}$} & 森 & \multicolumn{2}{|c|}{ 田 } & 勝* \\
\hline & 関 & \multicolumn{2}{|c|}{ 伸 } & 光 \\
\hline & 岡 & 本 & 正 & 紀** \\
\hline & 越 & 知 & 憲 & 治** \\
\hline & 竹 & 内 & 正 & 文 \\
\hline
\end{tabular}

\section{ISOMETRIC DETRUSOR PRESSURE IN THE ENURETIC PATIENT}

Masaru Morita, Nobumitsu Seki, Masaki Okamoto

Kenji Ochi and Masafumi Takeuchi

Department of Urology (Director: Prof. M. Takeuchi, Ehime University School of Medicine, Ehime, Japan

A total of 37 subjects, including 6 normal boys and 31 patients with enuresis ( 20 males and 11 females) underwent studies of isometric detrusor pressures by voluntary and forced flow-stop techniques.

There were no statistical differences in maximum isometric detrusor pressures and speed of detrusor contractions between normal boys and male enuretics. There was a significant difference $(p<0.05)$ in the parameter of the isometric detrusor pressure rise above the maximum detrusor pressure between normal boys and male enuretics with unstable bladders. There were ly significant differences $(\mathrm{p}<0.05)$ in maximum isometric detrusor pressures obtained by these two techniques between male enuretics with stable bladder and those with unstable bladders. There also was a statistical difference in the parameter of the isometric detrusor pressure rise above the maximum detrusor pressure between these patients.

Maximum isometric pressures obtained with two flow-stop techniques in male enuretics were significantly higher than those in female enuretics $(\mathrm{p}<0.01,0.05)$. Maximum isometric detrusor pressures obtained by the two flow-stop techniques were significantly higher than maximum detrusor pressures in normal boys and patients with enuresis. There were no statistical differences in the speed of detrusor contraction between normal boys and male and female patients with enuresis.

There were relatively good correlations between maximum isometric pressure and speed of detrusor contraction obtained by the two flow-stop techniques $(r=0.629,0.672)$.

要旨: 正常男児 6 例, 遺尿症31例（男20例, 女11例）で外尿道括約筋による意識的尿流中断と陰茎部尿 道, 又は膀胱頝部でのバルーンカテーテルによる強制的尿流中断による等容性排尿筋収縮を検討した。

正常男児と男子遺尿症では意識的及び強制的尿流中断により得られた等容性排尿筋収縮圧 $\left(\mathrm{P}_{\text {iso }}(\mathrm{v})\right.$, (f)) 及び排尿筋収縮スピードには統計学的な有意差はみられなかった。しかし, 強制的な方法で得られ た等容性排尿筋収縮圧 ( $\left.\mathrm{P}_{\mathrm{iso}}(\mathrm{f})\right)$ と最大排尿筋圧 ( $\left.\mathrm{P}_{\text {det }}, \mathrm{max}\right)$ の差のパラメーターに正常男児と不安定 膀胱を示した男子遺尿症との間で $\mathrm{p}<0.05 て ゙$ 統計学的な有意差がみられた。 そして, 男子遺尿症に拈いて は不安定膀胱を示した群と示さなかった群の間で $\mathrm{P}_{\text {iso }}(\mathrm{v})$ と (f) に $\mathrm{p}<0.05 て ゙$ 統計学的な有意差がみられ た。これらの群の間には $\mathrm{P}_{\text {iso }}(\mathrm{v})$ と $\mathrm{P}_{\mathrm{det}}, \max$ の差のパラメーターにも $\mathrm{p}<0.05 て ゙$ 有意差がみられた。

男子と女子の遺尿症患者の間では $\mathrm{P}_{\text {iso }}(\mathrm{v})$ と ( $\left.\mathrm{f}\right)$ にそれぞれ $\mathrm{p}<0.05,0.01$ で統計学的なな有意差がみ られ, 男子の方が高值を示した。正常男児と遺尿症において $\mathrm{P}_{\mathrm{iso}}(\mathrm{v})$, (f)共にそれぞれ $\mathrm{P}_{\mathrm{det}}, \max よ り$ 統 計学的に有意に高值を示した。排尿筋収縮スピードには正常男児, 男子と女子の遺尿症患者の 3 群の間

*こうない坂医院

** 衣山クリニック 
には有意差はみられなかった。

$\mathrm{P}_{\mathrm{iso}}(\mathrm{v}),(\mathrm{f})$ はそれぞれ収縮スピードとある程度の相関関係を認めた（r=0.672, 0.629）。

\section{緒言}

遺尿症の原因として膀胱機能の面からは不随意の膀 胼収縮を生じる症例が多い事, 中枢神経系の発達又は 成熟の遅延, 睡眠との関係, 遺伝的因子, 器質的な尿 路疾患, 精神的因子などが述べられて㧍り ${ }^{11}$ ，遺尿症は 1つの症候群であると考光られる，遺尿症に対する尿 水力学的な検討は古くから行われており ${ }^{2)}$, 最近, Mahony $ら^{3)}$ は膀胱内圧測定に括いて不随意の膀胱収縮 を示す症例が多いことを報告し，更に立位での膀胖内 圧測定，尿流中断試験での膀胱内圧の上昇，尿失禁の 有無により遺尿症の分類を行っている。

我々は意識的及び強制的な 2 種類の尿流中断方法を 用いて，排尿時の等容性排尿筋収縮圧測定を正常人及 び種々の疾患での男女で行い報告している(4)5)。そし て，等容性排尿笳収縮圧の測定は排尿筋収縮の質を評 価する上で重要なパラメーターとなると考兄られた。 そこで，今回，我々は遺尿症の患者を対象として排尿 筋収縮の面から尿水力学的な検討を行ったので報告す る。

\section{対象と方法}

正常男児 6 例，遺尿症31例（男20例，女11例）で検 討を行った，遺尿症患者は小児が多い為，今回の検討 では対象とする年齢は 20 歳以下とした，正常男児は排 尿歴に異常がなく, 検尿, 尿流測定にて正常であるも のとした。年齢は正常男児は 3 歳から 10 歳 $(5.7 \pm 2.4$,

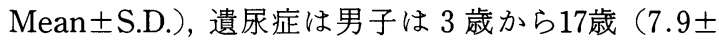
$3.2)$, 女子は 7 歳から 16 歳 $(10.6 \pm 2.9)$ であった。男 子の遺尿症では夜尿のみを示したものは 6 例, 昼間遺 尿のみを示したものは 1 例で, 他の 13 例は昼間及び夜 間の遺尿を示した。女子の遺尿症では夜尿のみを示し たものは 3 例，昼間遺尿のみを示したものは 3 例で, 他の 5 例は昼間及び夜間の遺尿を示した。男子の遺尿 症の 1 例に球部尿道での狭窄がみられ, 又, 女子の遺 尿症では 1 例に外尿道口での狭窄がみられた。

膀脱圧の測定方法としては, 男子では4Frのアトム 栄養チューブを経尿道的に留置し，女子では $4 \mathrm{Fr}$ の coiled-tip catheter とバルーンカテーテルを組み合わ せたカテーテルを経尿道的に留置した。 そして，これ らのカテーテルは生理食塩水による膀脱充満と排尿時 の膀胱圧測定に用いられた。腹圧測定には14 16Fr の バルーンカテーテル (open-end)を用い，肛門から直
腸に插入して測定された。 厌測定の基準は恥骨上縁と し, 排尿筋圧は電気的に膀胱圧から腹圧を差し引いて 求められた。骨盤底筋群の筋電図測定は同芯針電極 （DISA 13L49）又は表面電極（DISA 13L20）を用い て行った。検査は男子は立位, 女子は座位で行い, 膀 胱圧, 腹腔圧, 排尿筋圧, 筋電図, 尿流率の同時測定 がほぼ最大尿意に近い膀脱容量で 2 〜 回行われた。 次いで, 排尿中断時の等容性排尿筋収縮圧 $\left(\mathrm{P}_{\text {iso }}\right.$ と略 す）の測定が行われた。排尿中断はほぼ最大尿流を示 した時点で行われ, 意識的な方法は男女共に尿道外括 約筋を収縮させて行わせた。強制的な尿流中断は男子 では手指で陰茎部尿道を圧迫し，女子では膀胼䅡部で バルーンを膨らませて行った。 この際, 尿流が中断さ れても排尿を持続するように患者に命じ， $\mathrm{P}_{\text {iso }}$ が求め られた，排尿が持続されているかどうかは骨盤底筋群 の筋電図から判定された。等容性排尿筋収縮での収縮 スピードは我々が以前に報告4)したように，意識的及 び強制的尿流中断の時の最初の直線的に上昇する相の 傾きから算出した。不安定膀胼の判定はほぼ最大尿意 時に立位又は座位, 咳などの誘発試験を行い, 膀胱収 縮が誘発されたものを不安定膀胱とした。

圧測定, 筋電困測定, 尿流測定とその記録は DISA urodynamic equipment 用いて行った。 統計分析は $\mathrm{t}$ 検定を用いた。

\section{結 果}

正常男児 6 例, 遺尿症31例（男20例, 女11例）の計 37例で検討を行った。

Fig. 1 3 5 歳の正常男子, 17歳の男子遺尿症患 者，12歳の女子遺尿症患者でのそれぞれの意識的及び 強制的尿流中断による等容性排尿笳収縮曲線を示す. それぞれの意識的尿流中断による等容性排尿筇収縮曲 線は直後の直線的に上昇する部分とそれに続く上に凸

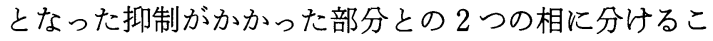
とができる、強制的尿流中断による等容性排尿筋収縮 曲線は直後の直線的に上昇する部分ととれに続く緩徐 に上昇する部分，そしてほぼ平坦となった部分との 3

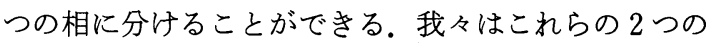
尿流中断方法で得られる曲線の最初の直線的に上昇す る部分を排尿筋収縮スピードをあらわすものとみなし た. Fig. 1での正常男子での意識的尿流中断による $\mathrm{P}_{\text {Iso }}$ は $82 \mathrm{cmH}_{2} \mathrm{O}$ で収縮スピードは $55.4 \mathrm{cmH}_{2} \mathrm{O} / \mathrm{sec}$, 
Fig. 1 Maximum isometric detrusor pressures $\left(\mathrm{P}_{\text {iso }}\right)$ in 5-year-old boy. A, curve obtained by stopping urinary flow with external urethral sphincter voluntarily. B, curve obtained by stopping urinary flow with fingers forcibly.

A

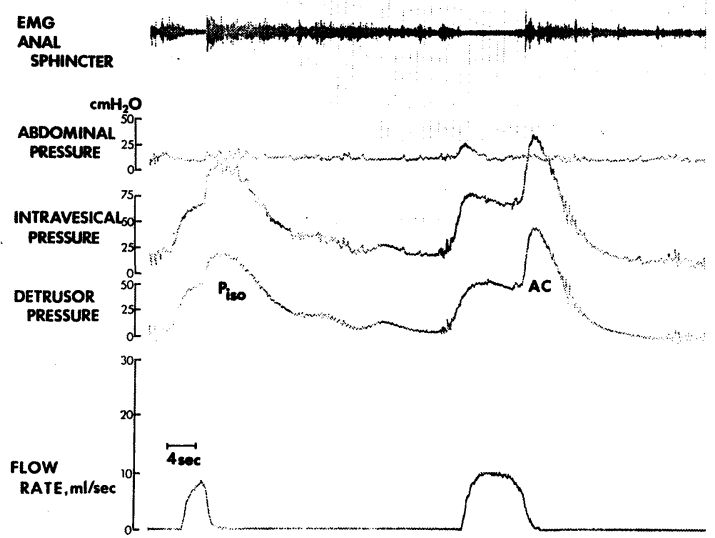

B
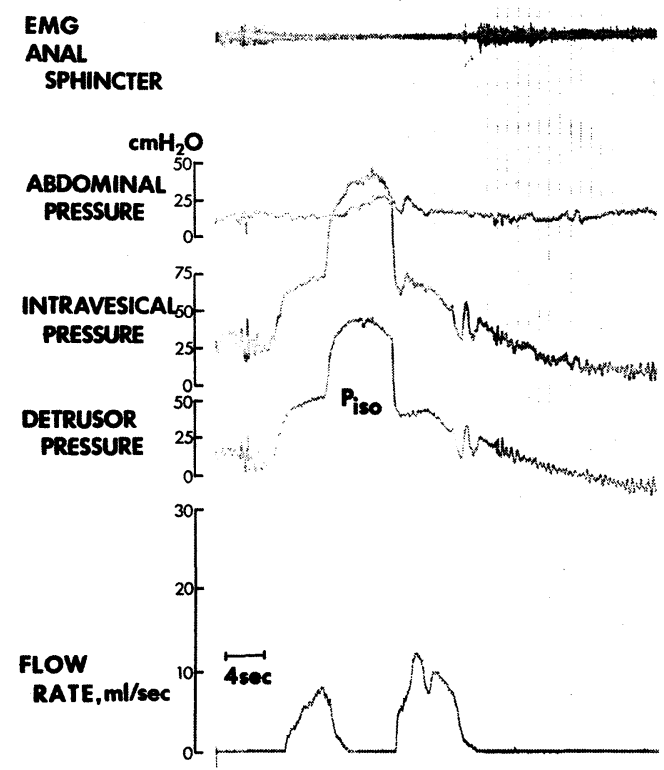

そして強制的尿流中断ではそれぞれ $103 \mathrm{cmH}_{2} \mathrm{O}$ と $48.4 \mathrm{cmH}_{2} \mathrm{O} / \mathrm{sec}$ であった. Fig. 2での男子遺尿症患者 での意識的尿流中断による $\mathrm{P}_{\mathrm{is}}$ は $158 \mathrm{cmH}_{2} \mathrm{O}$ で, 収縮 スピードは $97.2 \mathrm{cmH}_{2} \mathrm{O} / \mathrm{sec}$, そして強制的尿流中断で

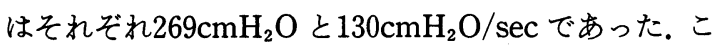
の症例では強制的尿流中断は最初は不充分であり, データーとしては充分に尿流が中断された時点からの
Fig. 2 Maximum isometric detrusor pressures $\left(P_{\text {iso }}\right)$ in 17-year-old boy with diurnal and nocturnal enuresis. $A, 2$ phases of $P_{\text {iso }}$ curve obtained by stopping urinary flow with voluntary flow-stop technique. $B, 3$ phases of $P_{\text {iso }}$ curve obtained with forced flow-stop technique. Flow was stopped incompletely in early stage.

A

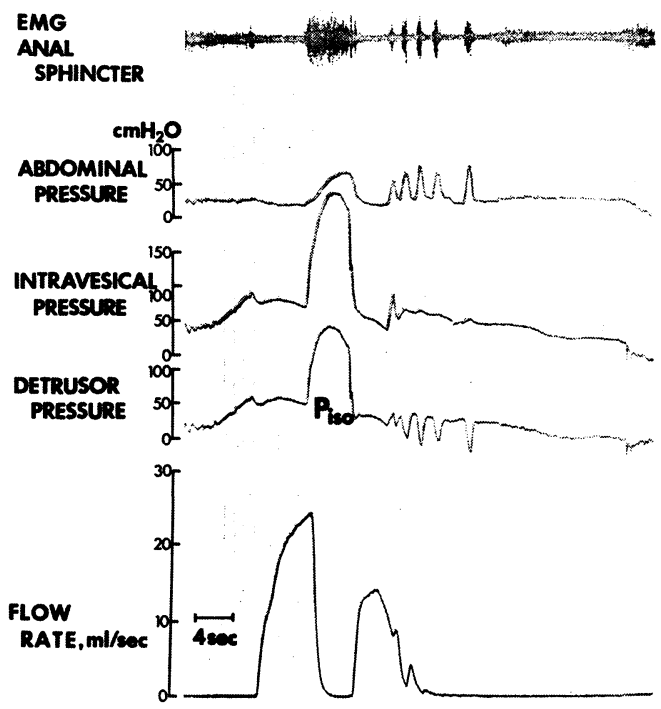

B

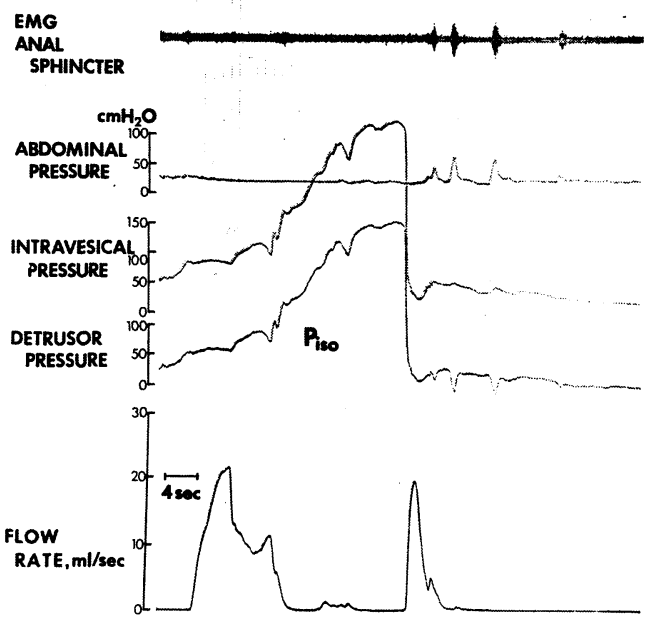

部分を採用している．Fig. 3での女子遺尿症患者での 意識的尿流中断による $\mathrm{P}_{\mathrm{iso}}$ は $54 \mathrm{~cm} \mathrm{H}_{2} \mathrm{O}$ で, 収縮ス ピードは $42.9 \mathrm{cmH}_{2} \mathrm{O} / \mathrm{sec}$, そして強制的尿流中断では

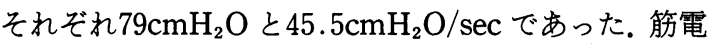
図には一部アーティファクトがみられる。 
Fig. 3 Maximum isometric detrusor pressures $\left(P_{\text {iso }}\right)$ in 12-year-old girl with nocturnal enuresis. A, 2 phases of $P_{\text {iso }}$ curve obtained with voluntary flow-stop technique. $\mathrm{B}, 3$ phases of $\mathrm{P}_{\text {iso }}$ curve obtained with forced stop-flow technique.

A

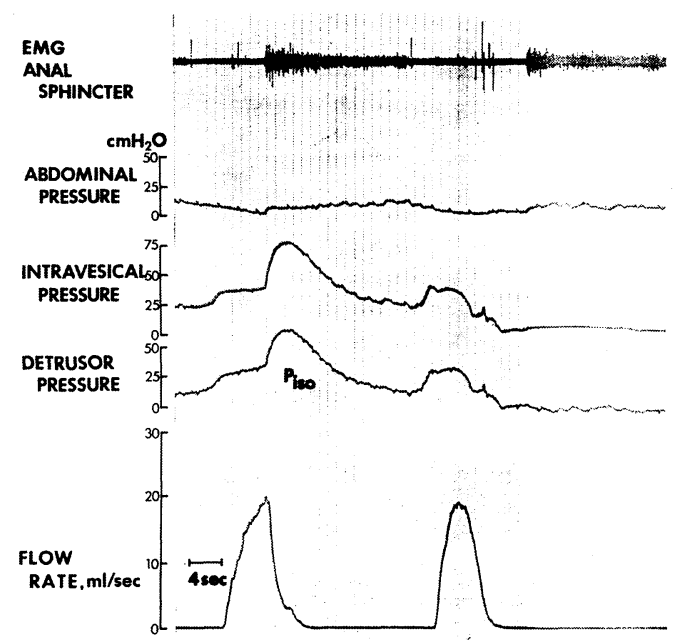

B

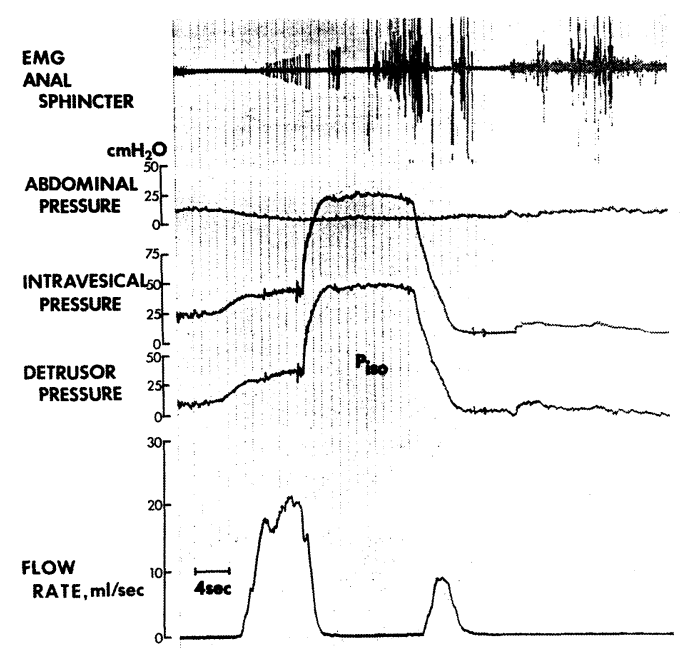

Table 1飞正常男児, 男子及び女子遺尿症での排尿 時最大排尿筋収縮圧 $\left(\mathrm{P}_{\mathrm{det}}, \mathrm{max}\right)$, 意識的及び強制的尿 流中断によって得られた $\mathrm{P}_{1 \text { so }}$ とその収縮スピードが示 されている，各群間の検討は正常男児と男子遺尿症, 男子と女子の遺尿症で行った。 その結果, 年齢は男子 と女子の遺尿症患者の間で $\mathrm{p}<0.05$ で有意差がみら れ，女子の方が年齢が高かった. $\mathrm{P}_{\mathrm{det}}, \mathrm{max}$ は男子と女 子の遺㽷症患者の間で $\mathrm{p}<0.05$ で有意差がみられ，男
Table 1 Mean and standard deviations of years and parameters of pressure-flow-electromyographic studies in volunteers and patients with enuresis.

\begin{tabular}{|c|c|c|c|}
\hline & \multirow{2}{*}{$\begin{array}{c}\text { Volunteers } \\
\text { (male, } 6 \text { cases) }\end{array}$} & \multicolumn{2}{|c|}{ Enuresis } \\
\hline & & (male, 20 pts.) & (female, 11 pts.) \\
\hline yrs. & $5.7 \pm 2.4$ & $7.9 \pm 3.2^{* *}$ & $10.6 \pm 2.9^{* *}$ \\
\hline $\begin{array}{l}\text { Maximum detrusor pressure } \\
\left(\mathrm{cmH}_{2} \mathrm{O}\right)\end{array}$ & $46.4 \pm 7.6^{* *}$ & $51.0 \pm 14^{*, * *}$ & $41.6 \pm 9.9^{* * * *}$ \\
\hline \multicolumn{4}{|l|}{$\begin{array}{l}\text { Maximum isometric detrusor } \\
\text { pressure }\left(\mathrm{cmH}_{2} \mathrm{O}\right) \text { : }\end{array}$} \\
\hline $\begin{array}{l}\text { Voluntary flow-stop } \\
\text { technique }\end{array}$ & $93.8 \pm 29.4^{* *}$ & ${ }^{115 \pm 38^{*}}+* *$ & $84.8 \pm 35.2^{*, * *}$ \\
\hline $\begin{array}{l}\text { Forced flow - stop } \\
\text { technique }\end{array}$ & $115 \pm 44^{* *}$ & $150 \pm 52^{* * * *}$ & $110 \pm 30.5^{*}$ \\
\hline \multicolumn{4}{|l|}{$\begin{array}{l}\text { First slope of curve } \\
\text { obtained with: }\end{array}$} \\
\hline $\begin{array}{l}\text { Voluntary flow - stop } \\
\text { technique }\left(\mathrm{cmH}_{2} \mathrm{O} / \mathrm{sec} \text {.) }\right.\end{array}$ & $77.5 \pm 35.0$ & $\begin{array}{r}103 \pm 56 \\
(n=18)\end{array}$ & $80.1 \pm 51.6$ \\
\hline $\begin{array}{l}\text { Forced flow - stop } \\
\text { technique }\left(\mathrm{cmH}_{2} \mathrm{O} / \mathrm{sec} .\right)\end{array}$ & $87.5 \pm 48.7$ & $115 \pm 48^{*}$ & $\underset{(n=9)}{68.7 \pm 25.1^{*}}$ \\
\hline
\end{tabular}

子の方が高値を示した。意識的尿流中断により得られ た $\mathrm{P}_{\text {iso }}\left(\mathrm{P}_{\text {iso }}(\mathrm{v})\right)$ は男子と女子の遺尿症患者の間で $\mathrm{p}<0.05$ で有意差がみられ，男子の方が高値を示した。 正常男児と男子の遺尿症患者の間では各種のパラメー ターの有意差はみられなかった。強制的尿流中断によ り得られた $P_{\text {iso }}\left(P_{\text {iso }}(f)\right)$ は男子と女子の遺尿症患者 の間で $\mathrm{p}<0.01 て ゙$ 有意差がみられ，男子の方が高値を 示した。意識的尿流中断により得られた排尿筋收縮ス ピード $\left(\mathrm{Sp}_{\mathrm{sso}}(\mathrm{v})\right)$ は各群間での有意差はみられなかっ た。強制的尿流中断により得られた排尿筋収縮スピー ド（ $\mathrm{Sp}_{\text {iso }}$ （f））は男子と女子の遺尿症患者の間で $\mathrm{p}<$ $0.01 て ゙$ 有意差がみられ，男子の方が高值を示した，以 上のよらに，各群間での検討から正常男児と男子遺尿 症群間では各種パラメーターには有意差がみられず, 男子と女子の遺尿症群間で有意差がみられたパラメー ターがあった。

次に各群でのそれぞれのパラメーター間での有意差 の検討を行った。正常男児では $\mathrm{P}_{\mathrm{det}}, \max$ と $\mathrm{P}_{\text {iso }}(\mathrm{v})$, $\mathrm{P}_{\mathrm{det}}, \max$ と $\mathrm{P}_{\text {iso }}(\mathrm{f})$ との間にそれぞれ $\mathrm{p}<0.05$ で有意 差がみられたが $\mathrm{P}_{\text {iso }}$ (v) と（f)の間には有意差はみら れなかった、 又, $\mathrm{Sp}_{\mathrm{iso}}(\mathrm{v})$ と（f)の間にも有意差はみら れなかった。男子の遺尿症群では $\mathrm{P}_{\text {det }}, \max$ と $\mathrm{P}_{\text {iso }}$ (v)， $\mathrm{P}_{\text {det }}, \max$ と $\mathrm{P}_{\text {iso }}(\mathrm{f})$ との間にそれぞれ $\mathrm{p}<0.01 て ゙$ 有意差がみられ， $\mathrm{P}_{\mathrm{Iso}}(\mathrm{v})$ と（f）の間に $\mathrm{p}<0.05$ で有意 差がみられた. $\mathrm{Sp}_{\text {iso }}(\mathrm{v})$ と(f)の間には有意差はみられ なかった。女子の遺尿症群では $\mathrm{P}_{\mathrm{det}}, \max$ と $\mathrm{P}_{\text {iso }}$ (v), $\mathrm{P}_{\text {det }}, \max$ と $\mathrm{P}_{\text {iso }}(\mathrm{f})$ との間にそれぞれ $\mathrm{p}<0.01 て ゙$ 有意 差がみられ， $\mathrm{P}_{\text {iso }}(\mathrm{v})$ と(f)の間には有意差はみられな かった。 又, $\mathrm{Sp}_{\text {iso }}(\mathrm{v})$ と(f)の間にも有意差はみられな 
Fig. 4 Correlation between isometric detrusor pressure $\left(\mathrm{P}_{\text {iso }}\right)$ and speed of detrusor contraction $\left(\mathrm{Sp}_{\mathrm{iso}}\right)$.

A, voluntary $(v)$ flow-stop technique. $y=1.11 x+3.81, r=0.672$. B, forced flowstop technique. $\mathrm{y}=1.66 \mathrm{x}-30.4, \mathrm{r}=0.629$.

$\triangle$, volunteer $\bigcirc$, male enuresis
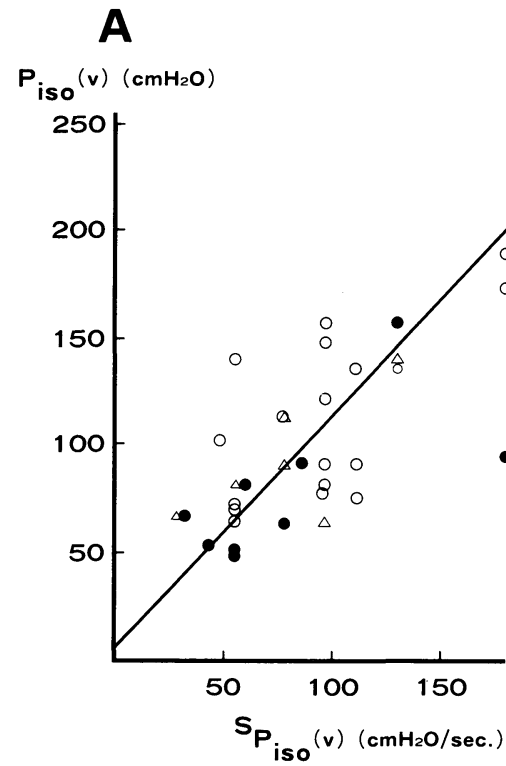

かった．以上のように，各群でのそれぞれのパラメー ター間では $\mathrm{P}_{\mathrm{iso}}(\mathrm{v})$ と ( $\mathrm{f}$ )が $\mathrm{P}_{\mathrm{det}}, \mathrm{max} よ り$ 有意に高值 を示し, $\mathrm{P}_{\text {iso }}(\mathrm{v})$ と(f)では男子の遺尿症群において有 意に $\mathrm{P}_{\text {iso }}(\mathrm{f})$ が高值を示した. $\mathrm{Sp}_{\text {iso }}(\mathrm{v})$ と(f)では各群 共に有意差はみられなかった。

次に男子遺尿症 20 例に括いて夜尿のみがみられた群 6 例と昼間及び夜間遺尿（昼間遺尿のみも含む）の群 14例，そして正常男児 6 例の 3 群で $\mathrm{P}_{\mathrm{det}}, \max , \mathrm{P}_{\text {iso }}$ (v), (f)の 3 つのパラメーターに関して検討を行った. この結果, $\mathrm{P}_{\mathrm{det}}, \max$ に夜尿のみの群 $\left(34.4 \pm 21.1 \mathrm{cmH}_{2}\right.$ O, Mean \pm S.D. ) と昼間及び夜間遺尿の群 $(55.1 \pm 13.3$ $\mathrm{cmH}_{2} \mathrm{O}$ ) との間で $\mathrm{p}<0.05$ と有意差がみられた。男子 遺尿症 20 例中に不安定膀胱を示した症例は11例あっ た. そこで, 不安定膀胱を示した群と示さなかった群, そして正常男児の 3 群で $\mathrm{P}_{\text {det }}, \max , \mathrm{P}_{\text {iso }}$ (v), (f)の 3 つのパラメーターの検討を行った。 この結果, $\mathrm{P}_{\text {iso }}(\mathrm{v})$ に不安定膀胼を示した群 $\left(133 \pm 39 \mathrm{cmH}_{2} \mathrm{O}\right)$ と示さな かった群 $\left(97.5 \pm 28.7 \mathrm{cmH}_{2} \mathrm{O}\right)$ との間で $\mathrm{p}<0.05$ と有 意差がみられ，そして， $\mathrm{P}_{\text {iso }}$ (f)でも不安定膀胖を示し た群 $\left(170 \pm 59 \mathrm{cmH}_{2} \mathrm{O}\right)$ と示さなかった群（126士30 $\mathrm{cmH}_{2} \mathrm{O}$ ）との間で $\mathrm{p}<0.05$ と有意差がみられた. $\mathrm{P}_{\text {iso }}$ (v)，(f)共にいずれも不安定膀胖を示した群の方が示

\section{B}

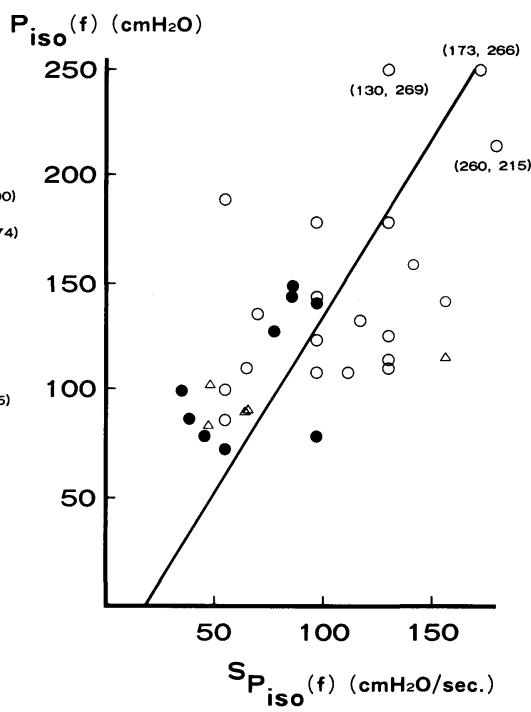

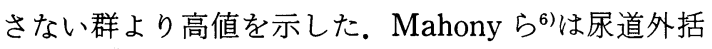
約筋で尿流を中断した場合, 膀胱圧が $15 \mathrm{cmH}_{2} \mathrm{O}$ 以上 上昇した場合，排尿反射の元進が考㝋られるとしてお り，これに基づいて遺尿症の分類を行っている3). 我々 も今回のデーターを用いて $\mathrm{P}_{\text {iso }}(\mathrm{v}), \mathrm{P}_{\text {iso }}(\mathrm{f})$ とそれぞ れの $\mathrm{P}_{\mathrm{det}}, \max$ の差及び $\mathrm{P}_{\text {iso }}(\mathrm{f})$ と $\mathrm{P}_{\text {iso }}(\mathrm{v})$ との差をパ ラメーターとして正常男児群, 男子遺尿症で夜尿のみ の群と昼間及び夜間遺尿の群, 不安定膀脱を示した群 と示さなかった群の 5 群で統計学的な検討を行った。 この結果, $\mathrm{P}_{\mathrm{Iso}}(\mathrm{v})$ と $\mathrm{P}_{\mathrm{det}}, \max$ の差のパラメーターに 不安定膀胼を示した群 $\left(77.9 \pm 32.9 \mathrm{cmH}_{2} \mathrm{O}\right)$ と示さな かった群 $\left(49.5 \pm 25.4 \mathrm{cmH}_{2} \mathrm{O}\right)$ との間で $\mathrm{p}<0.05$ と有 意差がみられた。 又, $\mathrm{P}_{\mathrm{iso}}$ (f) と $\mathrm{P}_{\mathrm{det}}, \max$ の差のパラ メーターに正常男児 $\left(68.2 \pm 42.2 \mathrm{cmH}_{2} \mathrm{O}\right)$ と不安定膀 脱を示した群 $\left(117 \pm 56 \mathrm{cmH}_{2} \mathrm{O}\right)$ との間で $\mathrm{p}<0.05$ と有 意差がみられ, 更に, 同じパラメーターに不安定膀脱 を示した群と示さなかった群 $\left(77.9 \pm 20.1 \mathrm{cmH}_{2} \mathrm{O}\right)$ と の間で $\mathrm{p}<0.05$ と有意差がみられた.このように, 不安 定膀胱の有無により $\mathrm{P}_{\text {iso }}$ $\mathrm{P}_{\mathrm{det}}, \mathrm{max}$ と差のパラ メーターに統計学的な有意差がみられた. 女子遺尿症 においては症例数が少ない為, 男子と同じ検討は行わ なかった。女子遺尿症では11例中 5 例に不安定膀脱が 
みられた。

$\mathrm{P}_{\text {iso }}$ と排尿筋収縮スピードについての相関は Fig. 4 に示している．2 種類の尿流中断方法共にすずまずの 相関がみられた $(r=0.672,0.629)$.

\section{考 察}

遺尿症に対する尿水力学的な検討は多くはなされて いない，現在迄に，尿水力学的な検討の結果として不 安定膀胼の出現頻度が高いこと光7 や不安定尿道 (urethral instability) との関連帛，そして成人の遺尿 症での検討では资髄の仙骨神経部分の異常, 特に尿道 感覚の低下 ${ }^{9}$ が報告されている，遺尿症に対する分類 の試みとしてMcGuire とSavastano ${ }^{10)}$ は夜尿, 昼間 遺尿の有無，そしてその頻度により遺尿の程度を分類 し，これと膀胼内圧測定に抢ける膀胱収縮の生じた膀 脱容量を比較することにより検討を行っている．彼ら の報告では膀胼容量が $100 \mathrm{ml}$ から $300 \mathrm{ml}$ 迄は膀胼容量 と遺尿の程度とは関係しており, 又, 治癒率も同じで あるが膀脱容量が $300 \mathrm{ml}$ 以上では遺尿の程度が強くな り, 又, 治癒率も少し低下するという結果を得ている。

遺尿症と $\mathrm{P}_{\text {iso }}$ の測定に関しては Griffiths ${ }^{11}$, Mahony $ら^{3 / 6)}$, Susset $ら^{12)}$ の報告がみられる. Griffiths ${ }^{11}$ の報告は年齢がほとんど20歳以上の症例であるが，男 子の遺尿症では $\mathrm{P}_{\text {iso }}(\mathrm{v})$ が高值で収縮スピードは正常 の例が多く, 女子の遺尿症では特徵的な所見はみられ なかったとしている. Mahony ら ${ }^{3 / 6)}$ は意識的尿流中断 を行った場合, 正常人であれば排尿筇圧はほとんど上 昇せず，仙髄排尿中枢の亢進状態があれば $15 \mathrm{cmH}_{2} \mathrm{O}$ 以上の排尿筋圧の上昇がみられるとして，これに基づ いて遺尿症の分類を行っている. Susset $ら^{12}$ は遺尿症 群では $\mathrm{P}_{\text {iso }}$ (v)が高值を示す症例が多く，尿道の通過 障害が疑われる場合が多いと報告している，以前の 我々の報告4)では男子で正常人と遺尿症を比べると $\mathrm{P}_{\text {iso }}(\mathrm{v})$ ，(f) 共に遺尿症の方が正常人より高值を示し， 更に収縮スピードも高值を示した。しかし，この場合， 正常人は 23 歳から 49 歳 (平均 40 歳) であり, 遺尿症は 5 歳から17歳（平均 9 歳）と年齢に差があり，単純な 比較は無理だと考兄られた。 そこで, 我々が以前に報 告した ${ }^{4)}$ 正常成人男子 7 例と新しく 8 例を加えた 15 例 (20 62歳, 平均 42.4 歳) と今回の正常男児 6 例 $(3 \sim 10$ 歳, 平均5.7歳) の $\mathrm{P}_{\text {iso }}(\mathrm{v}),(\mathrm{f}), \mathrm{Sp}_{\text {iso }}(\mathrm{v})$, ( $\mathrm{f}$ )を比較 すると（Table 2) $\mathrm{P}_{\text {iso }}(\mathrm{v}),(\mathrm{f})$ に $\mathrm{p}<0.01$ で有意差が みられ，正常男児の方が高い值を示した，収縮スピー ドは $\mathrm{Sp}_{\text {iso }}$ (f) に $\mathrm{p}<0.05 て ゙$ 有意差がみられ, 正常男児 の方が高い値を示した. Susset ら ${ }^{13)}$ は加跉により膀胼
Table 2 Mean and standard deviations of years and parameters of pressure-flow-electromyographic studies in man and boy volunteers.

\begin{tabular}{|c|c|c|}
\hline & \multicolumn{2}{|c|}{ Male Volunteers } \\
\hline & $\begin{array}{c}\text { Adult } \\
\text { (15 cases) }\end{array}$ & $\begin{array}{l}\text { Child } \\
(6 \text { cases })\end{array}$ \\
\hline yrs. & $42.4 \pm 13.0$ & $5.7 \pm 2.4$ \\
\hline$\underset{\left(\mathrm{cmH}_{2} \mathrm{O}\right)}{\text { Maximum detrusor pressure }}$ & $38.0 \pm 11.3$ & $46.4 \pm 7.6$ \\
\hline \multicolumn{3}{|l|}{$\begin{array}{l}\text { Maximum isometric detrusor } \\
\text { pressure }\left(\mathrm{cmH}_{2} \mathrm{O}\right) \text { : }\end{array}$} \\
\hline $\begin{array}{l}\text { Voluntary flow-stop } \\
\text { technique }\end{array}$ & $54.1 \pm 17.9^{*}$ & $93.8 \pm 29.4^{*}$ \\
\hline $\begin{array}{l}\text { Forced flow - stop } \\
\text { technique }\end{array}$ & $63.8 \pm 27.3^{*}$ & $115 \pm 44^{*}$ \\
\hline \multicolumn{3}{|l|}{$\begin{array}{l}\text { First slope of curve } \\
\text { obtained with: }\end{array}$} \\
\hline $\begin{array}{l}\text { Voluntary flow - stop } \\
\text { technique }\left(\mathrm{cmH}_{2} \mathrm{O} / \mathrm{sec} \text {. }\right)\end{array}$ & $45.2 \pm 31.9$ & $77.5 \pm 35.0$ \\
\hline $\begin{array}{l}\text { Forced flow - stop } \\
\text { technique }\left(\mathrm{cmH}_{2} \mathrm{O} / \mathrm{sec} .\right)\end{array}$ & $34.4 \pm 24.1 * *$ & $87.5 \pm 48.7^{* *}$ \\
\hline
\end{tabular}

排尿筋には老齢の婦人以外はそれ程膠原線維の量は多 くなっていないと報告して打り，年齢による $\mathrm{P}_{\mathrm{iso}}$ の低 下は排尿に関する神経系（主に大脳での抑制系）の成 熟に関係しているかも知れない，今回の我々の検討に おいては正常男児は年齢が $3 \sim 10$ 歳 (平均 5.7 歳), 男 子遺尿症は $3 \sim 17$ 歳 (平均7.9歳) とほぼ同じ年齢層に できた。この結果, 正常男児と男子遺尿症の間には $\mathrm{P}_{\text {iso }}$ (v)，(f)及び収縮スピードには差がみられなかった。統 計学的に有意差がみられたパラメーターは $\mathrm{P}_{\text {iso }}$ (f) と $P_{\text {det }}, \max$ の差であり, これは正常男児と不安定膀胱を 示した遺尿症との間で有意差がみられた，正常男児と 不安定膀胼を示さない遺尿症ではこのパラメーターに は有意差はみられなかった。一方, 遺尿症では不安定 膀胼を示した群と示さない群は $\mathrm{P}_{\text {iso }}(\mathrm{v}),(\mathrm{f})$ に有意差 を認めた. 今回の我々の検討では各群の数が少なく, 統計学的な分析には無理があるかも知れない.しかし, Susset ら ${ }^{12)}$ は遺尿症で不安定膀胱と $\mathrm{P}_{\text {iso }}$ の関連の重 要性を述べ，今後の検討を示唆して扣り，少数例から の検討ではあるが，今回の我々の結果から $\mathrm{P}_{\text {iso }}$ といら パラメーターが不安定膀胱の有無と関係していたこと は, 今後, 不安定膀胱と $\mathrm{P}_{\text {iso }}$ が遺尿症のパラメーターと なり得ることを示すものだと考えられた。

Susset ら ${ }^{12)}$ は $\mathrm{P}_{\text {iso }}$ と尿道抵抗の関係から遺尿症で は尿道の通過障害が疑われる症例が多いとしている。 今回の我々の検討では膀胱内圧の測定に経尿道的な方 法(4Frのカテーテル)を用いて拈り，男児では特にカ テーテルが尿道抵抗をかなり修飾すると考兄られる。 この為, 今回は尿道抵抗に対する検討は行っていない。 しかし，年龄を考慮すると $\mathrm{P}_{\mathrm{iso}}$ は正常男児と遺尿症で 
は差がみられないよらであり， $\mathrm{P}_{\text {iso }}$ と尿道抵抗の関係 も年齢を考慮しなければ単純には関連づけられないか も知れないと考朰れれ。

$\mathrm{P}_{\text {iso } 0}$ 及び収縮スピードは前回の女性での検討) 及び 今回の検討から性と年齢により異なるようであった。 又，一般的に意識的及び強制的な尿流中断により得ら れた $\mathrm{P}_{\mathrm{iso}}$ は $\mathrm{P}_{\mathrm{det}}, \mathrm{max} よ り$ 高值を示し, 正常人以外では $\mathrm{P}_{\text {iso }}(\mathrm{f})$ が $\mathrm{P}_{\text {iso }}(\mathrm{v})$ より高値を示した。正常人に扮いて は症例が少ない為, $\mathrm{P}_{\text {iso }}(\mathrm{v})$ と(f)の間には有意差がみ られなかったが，大部分の症例では $\mathrm{P}_{\text {iso }}(\mathrm{f})$ の方が(v) より高値を示した。収縮スピードに扑いては 2 種類の 尿流中断法の差はみられない上らであった。 $\mathrm{P}_{\text {iso }}$ と収 縮スピードの間にはある程度の相関関係がみられるよ らであった。今後, 遺尿症と膀胖収縮といら面からの 検討として, 遺尿症と不安定膀胼と $\mathrm{P}_{\text {iso }}$ の関連, そし て, $\mathrm{P}_{\text {iso }}$ 加えた遺尿症の分類, $\mathrm{P}_{\text {iso }}$ と治療及び予後と の関係を明らかにしていくことが重要であると考兄ら れる。

\section{結 語}

正常男児，男子と女子の遺尿症患者で等容性排尿筋 収縮を検討した。

正常男児と男子遺尿症では $\mathrm{P}_{\text {iso }}$, 排尿筋収縮スピー ドには統計学的な有意差はみられなかったが，男子遺 尿症を不安定膀脱を示す群と示さない群に分けてそれ ぞれで検討を行うと統計学的に有意差のみられるパラ メーターが存在した。

男子と女子の遺尿症患者の間では $\mathrm{P}_{\text {iso }}(\mathrm{v}),(\mathrm{f})$ にそ れぞれ統計学的な有意差がみられ，男子の方が高値を 示した。

正常男児，遺尿症に㨟いて $\mathrm{P}_{\text {iso }}(\mathrm{v})$ ，(f) 共にそれぞ れ $\mathrm{P}_{\mathrm{det}}, \mathrm{max}$ より統計学的に有意に高值を示した。 そ して, $\mathrm{P}_{\text {iso }}(\mathrm{v})$ ，(f)共にそれぞれ排尿筋収縮スピードと ある程度の相関関係を認めた。

\section{文献}

1) Koff, S.A.: Enuresis. In : Campbell's Urology, 5th. ed., p. 2179-2192, The W.B. Saunders Co., philadelphia, 1986.

2) Linderholm, B.E. : The cystometric findings in enuresis. J. Urol., 96, 718-722, 1966.
3) Mahony, D.T., Laferte, R.O. and Blais, D.J.: Studies of enuresis. IX. Evidence of a mild form of compenstated detrusor hyperreflexia in enuretic children. J. Urol., 126, 520-523, 1981.

4) Morita, M.,Okamoto, M., Ochi, K. and Takeuchi, M.: Isometric detrusor pressure in the male patient : A comparison between voluntary urethral sphincter contraction and forced penile compression techniques. J. Urol., 134, 1161 $-1165,1985$.

5) 森田 勝, 関 伸光, 岡極正紀, 越知憲治, 竹内正 文：女性での等容性排尿筋收縮圧の測定. 日泌尿 会誌，投稿中.

6) Mahony, D.T., Laferte, R.O. and Blasis, D.J.: Incontinence of urine due to instability of micturition reflexes. part II. Pudendal nucleus instability. Urology, 15, 379-388, 1980.

7) 島田憲次, 桜井 勗, 生駒文彦, 時実昌泰, 林 知 厚, 佐藤義基, 永田 肇, 坂口 強, 寺川知良, 島 博基：小児下部尿路通過障害之潜在性神経因性膀 胼. 第 2 報：夜尿症の原因分析について。 日泌尿会 誌, 68, 636-643, 1977.

8) Penders, L., Leval, J. and Petit, R.: Enuresis and urethral instability. Eur. Urol., 10, 317 $-322,1984$.

9) Fidas, A., Galloway, N.T.M., McInnes, A. and Chisholm, G.D.: Neurophysiological measurements in primary adult enuresis,. Brit. J. Urol., 57, 635-640, 1985.

10) McGuire, E.J. and Savastano, J.A. : Urodynamic studies in enuresis and the nonneurogenic neurogenic bladder. J. Urol., 132, 299-302, 1984.

11) Griffiths, D.J.: Urodynamic assessment of bladder function. Brit,. J. Urol., 49, 29-36, 1977.

12) Susset, J.G., Brissot, R.B. and Regnier, C.H.: The stop-flow technique: A way to measure detrusor strength. J. Urol., 127, 489-494, 1982.

13) Susset, J.G., Servot-Viguier, D., Lamy, F., Madernas, P. and Black, R.: Collagen in 155 human bladders. Invest. Urol., 16, 204-206, 1978.

（1986年 8 月 6 日受付） 